\title{
Rheumatoid Arthritis: A Rare Cause of Cardiac Tamponade
}

\author{
Kardiyak Tamponadın Nadir Bir Nedeni: Romatoid Artrit
}

\author{
Yiğit ÇANGA, Kazım Serhan ÖZCAN, Mehmet Baran KARATAŞ, Gündüz DURMUŞ, İzzet Celal ERDİNLER
}

Department of Cardiology, Siyami Ersek Thoracic and Cardiovascular Surgery Center, Training and Research Hospital, Istanbul, Turkey

\begin{abstract}
Rheumatoid arthritis (RA) is a chronic multisystem disease of unknown cause which affects approximately $1 \%$ of the population. The typical characteristic of RA is persistent inflammatory synovitis which usually involves peripheral joints in a symmetric distribution. Systemic involvements of RA include pericarditis, pleuritis, vasculitis, entrapment neuropathy, interstitial lung disease and Sjogren and Felty syndromes. Echocardiographic and postmortem studies have shown that RA affects pericardium in nearly $50 \%$ of the patients. However, cardiac tamponade is a rare complication of RA. In this report, we present a surgically-treated 61-year-old female patient with cardiac tamponade secondary to loculated pericardial effusion.
\end{abstract}

Key words: Cardiac tamponade; pericardial effusion; pericardium; rheumatoid arthritis.

Rheumatoid arthritis (RA) is a chronic multisystem disease of unknown cause which affects approximately 1 to $3 \%$ of the population. The characteristic feature of RA is persistent inflammatory synovitis, usually involving peripheral joints in a symmetric distribution. Systemic involvements of RA include pericarditis, pleuritis, vasculitis, entrapment neuropathy, interstitial lung disease, and Sjogren's and Felty syndromes. As indicated by echocardiography and necropsy studies, RA affects the pericardium in approximately 50 percent of patients. ${ }^{[1]}$ Chronic asymptomatic pericardial effusion is more common than acute pericarditis. ${ }^{[2]}$ Cardiac tamponade is a rare complication of RA. In this report, we describe a surgically treated female patient with cardiac tamponade secondary to loculated pericardial effusion.
Romatoid artrit (RA) toplumun yaklaşık \%1'inde görülen, nedeni bilinmeyen, multisistem tutulumlu kronik bir hastalıktır. Hastalığın tipik özelliği genellikle periferik eklemleri simetrik dağılımlı olarak tutan persistan inflamatuar sinovittir. Romatoid artritin sistemik tutulumları perikardit, plörit, vaskülit, tuzak nöropatisi, interstisyel akciğer hastalığı, Sjogren ve Felty sendromlarıdır. Hastaların yaklaşık \%50'sinde RA'nın perikardı etkilediği, ekokardiyografik ve postmortem çalışmalarda gösterilmiştir. Buna rağmen, kardiyak tamponad RA'nın nadir bir komplikasyonudur. Bu yazıda, cerrahi olarak tedavi edilmiş olan kardiyak tamponada neden olan loküle perikardiyal effüzyonlu 61 yaşında bir kadın hasta sunuldu.

Anahtar sözcükler: Kardiyak tamponad; perikardiyal effüzyon; perikard; romatoid artrit.

\section{CASE REPORT}

Our case involved a 61-year-old female patient who had been diagnosed with seropositive and erosive RA 20 years previously. She had no extraarticular involvement and was using oral methotrexate $15 \mathrm{mg}$ once a week. The patient was admitted to another hospital having complained of progressive dyspnea, chest pain, and lower leg edema for more than 10 days. Pericardial effusion was detected by a thoracoabdominal computed tomography (CT) scan, and she was transferred to our hospital. At arrival, physical examination showed an arterial pressure of $110 / 70 \mathrm{mmHg}$, a pulse rate of 120 beats/min, a respiratory rate of $30 / \mathrm{min}$, and a body temperature of $37{ }^{\circ} \mathrm{C}$ with distended neck veins, mild hepatomegaly, and decreased heart 
sounds. The patient did not have arthralgia, and there were no signs or symptoms related to active RA. Electrocardiography (ECG) revealed atrial fibrillation with high ventricular response and low voltage. A chest X-ray showed cardiomegaly with clear lungs. Laboratory investigations showed a C-reactive protein level of $129 \mathrm{mg} / \mathrm{L}$, a sedimentation rate of $8 \mathrm{~mm} / \mathrm{h}$, a plasma D-dimer measurement of $998 \mathrm{ng} / \mathrm{mL}$, a white blood cell (WBC) count of 11.500 cells $/ \mathrm{mm}^{3}$, a platelet count of $428.000 / \mathrm{mm}^{3}$, and a moderate degree of anemia. A transthoracic echocardiogram (TTE) demonstrated a near total collapse of the right atrium and the right ventricle due to compression by an adjacent cystic structure covered with a thick membrane (Figure 1). When we examined the CT scan in light of these echocardiografic findings, we noticed that this large cystic structure had been misinterpreted as the right ventricle (Figure 2). On the CT scan, we found a bilateral pulmonary embolism but no masses or lymphadenopathy suggestive of malignancy. A color Doppler ultrasonography was performed which revealed the source of the embolism to be the presence of bilateral deep vein thrombosis at the lower extremity. Since the patient was symptomatic, surgery was planned. Surgical exploration via an anterolateral thoracotomy showed a viscous loculated material compressing the right ventricle and the right atrium anterolaterally along with a thickened pericardium. The surgeon also noted the fibrous thickening which caused septation and compartmentation of the pericardium and a $1500 \mathrm{cc}$ hemorrhagic jelly-like fluid drainage. Analysis of the fluid revealed a $\mathrm{pH}$ of 7.15, a WBC count of $115 / \mathrm{mm}^{3}$ (predominantly lymphocytes),

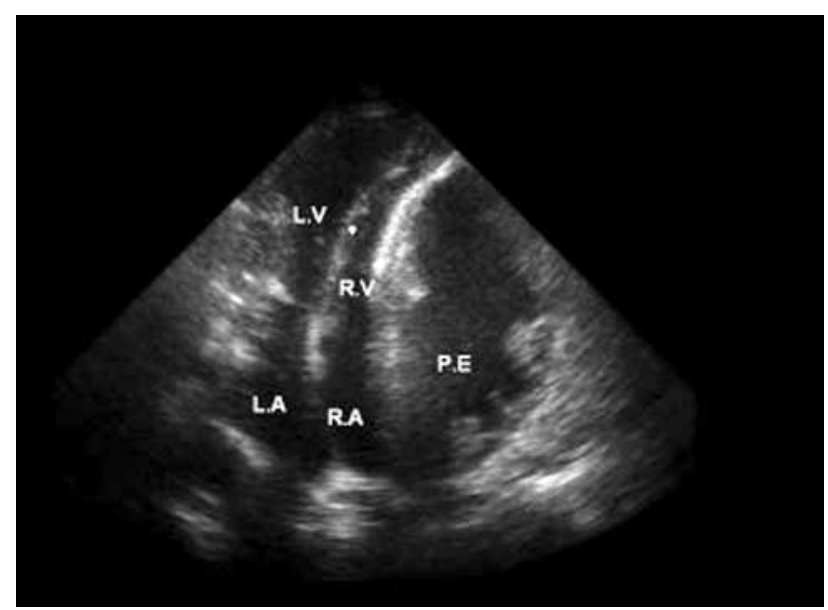

Figure 1. A transthoracic echocardiogram in apical fourchamber view shows the near total collapse of the right heart caused by lateral pericardial effusion. P.E: Pericardial effusion; RA: Right atrium; RV: Right ventricle; LA: Left atrium; LV: Left ventricle. a protein level of $5.8 \mathrm{~g} / \mathrm{dl}$, an $\mathrm{LDH}$ level of $780 \mathrm{U} / \mathrm{L}$, and a glucose level of $2 \mathrm{mg} / \mathrm{dl}$. A pathologic examination of the pericardial material revealed prominent infiltration with lymphocytes and plasma cells, which correlates well with chronic inflammation. Bacterial cultures and a polymerase chain reaction (PCR) test for Mycobacterium tuberculosis were all negative with no malignant cells on cytological examination. Both the pathologic specimen and the pericardial fluid had no findings consistent with tuberculosis and malignancy. The Mantoux test was also negative.

After the operation, a TTE demonstrated that the right chambers were free of compression. Warfarin was begun for the pulmonary embolism with a targeted international normalized rate (INR) of 2.0-3.0. The patient had an uneventful postoperative course and was discharged from the hospital on warfarin treatment with a good hemodynamic status. After three months, the patient was asymptomatic, and there was no pericardial effusion on control echocardiography.

\section{DISCUSSION}

In necropsy studies on patients with RA, the incidence of pericarditis varies from $11 \%$ to $50 \% \cdot{ }^{[3]}$ Echocardiography detects pericardial effusions and other sequelae of pericarditis in about a third of patients with RA. Nevertheless, symptomatic rheumatoid pericarditis is uncommon. Patients with rheumatoid pericardial disease are generally older and have long-standing RA. ${ }^{[1]}$ Pericardial involvement usually manifests itself as diffuse pericardial effusion. In our case, the pericardial effusion was loculated and caused pericardial tamponade, a rare complication of RA. Also, RA is one

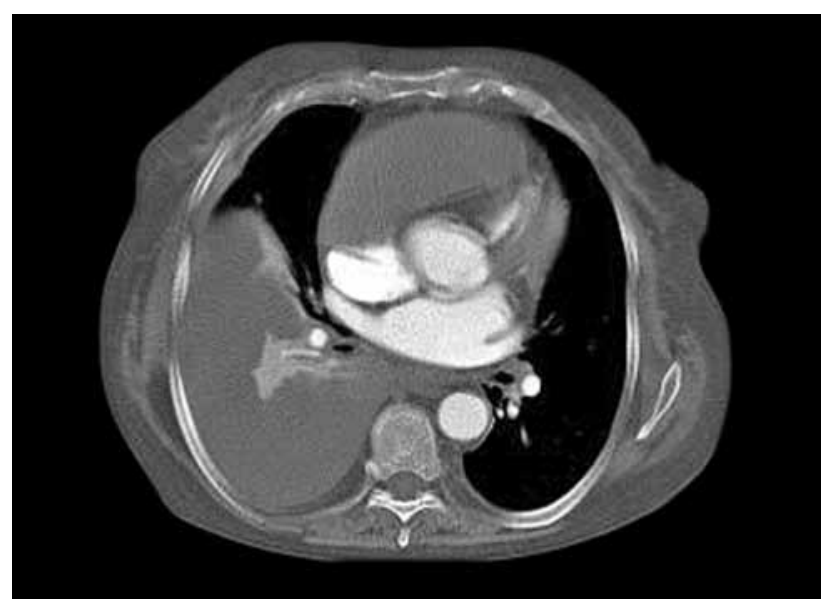

Figure 2. A computed tomography scan shows the loculated pericardial effusion that had been misinterpreted as the right ventricle at initial examination. Pleural effusion was also shown. P.E: Pericardial effusion. 
of the least common etiologies of cardiac tamponade. Escalante et al ${ }^{[4]}$ noted that the prevalence of cardiac compression with tamponade in RA varied from $0.22 \%$ to $0.5 \%$. In differential diagnoses, pericardial effusion can be idiopathic, viral, bacterial, uremic, neoplastic, or traumatic and can include tuberculosis, hydatid cyst, and postmyocardial infarction. It can also be drug-related. ${ }^{[5]}$ Tuberculosis and neoplastic effusion should be considered in the differential diagnosis of the hemorrhagic pericardial effusion. Thoracoabdominal CT did not reveal any mass compatible with malignancy. Tumor markers were all negative, and no malignant cells were found on cytological examination of the pericardial fluid. In light of these findings, we excluded malignancy as the cause of the pericardial effusion. Tuberculosis infection was also considered as a reason for effusion; however, the patient had no history of contact with tuberculosis, the Mantoux and the PCR tests were negative, and there were no pathological findings consistent with tuberculosis. In this case, due to the previous diagnosis of RA, we considered RA-related or methotrexate-related pericardial effusion. Methotrexate may provoke serositis, even with low doses, after just a few weeks of therapy. ${ }^{[6]}$ The symptoms associated with pericarditis become prominent after methotrexate ingestion and resolve after patients stop taking the drug. ${ }^{[7]}$ In our case, the patient had been taking methotrexate for a long time. The symptoms of pericarditis were progressive and independent of methotrexate ingestion, so we excluded methotrexaterelated effusion. For our case, the clue was to look at the fluid analysis. In rheumatoid pericardial effusion, the $\mathrm{pH}$ is low, and the glucose level is very low. Our patient had classic rheumatoid pericarditis with a high WBC count, elevated lactate dehydrogenase (LDH), and low glucose concentration in the pericardial fluid. Because the pericardial fluid was loculated and not suitable for pericardiocentesis, surgery was the preferred treatment. Without surgical intervention, the two-year mortality for rheumatoid pericarditis can be in excess of $50 \%$, but these deaths are frequently attributed to causes other than recurrent cardiac tamponade.

The coexistence of the pulmonary embolism as a consequence of deep vein thrombosis is another interesting point of this case. Several studies have suggested that RA confers a prothrombotic state featuring abnormalities in coagulation and fibrinolytic systems together with an altered state of platelet reactivity. Endothelial dysfunction, hypercoagulability, prothrombotic conditions, inflammatory markers, immobility, and complications following major knee or hip replacement contribute to the increased risk of thromboembolism in patients with RA. ${ }^{[8]}$ Our patient had a history of a period of immobilization due to disability which served as a predisposing factor for the pulmonary embolism.

In conclusion, RA-related, loculated pericardial effusion should be kept in mind as a rare cause of cardiac tamponade.

\section{Declaration of conflicting interests}

The authors declared no conflicts of interest with respect to the authorship and/or publication of this article.

\section{Funding}

The authors received no financial support for the research and/or authorship of this article.

\section{REFERENCES}

1. Mandell B, Hoffman G. Rheumatic diseases and the cardiovascular system. In: Zipes DP, Libby P, Bonow R, Braunwald E. editors. Braunwald's heart disease. 7th ed. Philadelphia: Saunders; 2004. p. 2101-16.

2. Coblyn SJ, O'Gara TP. The heart in rheumatic disease. In: Hochberg CM, Silman JA, Smolen SJ, editors. Rheumatology. Philadelphia: Mosby; 2003. p. 305-13.

3. Thadani U, Iveson JM, Wright V. Cardiac tamponade, constrictive pericarditis and pericardial resection in rheumatoid arthritis. Medicine (Baltimore) 1975;54:261-70.

4. Escalante A, Kaufman RL, Quismorio FP Jr, Beardmore TD. Cardiac compression in rheumatoid pericarditis. Semin Arthritis Rheum 1990;20:148-63.

5. Kitas G, Banks MJ, Bacon PA. Cardiac involvement in rheumatoid disease. Clin Med 2001;1:18-21.

6. Savoia F, Gaddoni G, Casadio C, Patrizi A, Spadola G, Bassi $\mathrm{P}$, et al. A case of aseptic pleuropericarditis in a patient with chronic plaque psoriasis under methotrexate therapy. Dermatol Online J 2010;16:13.

7. Mohyuddin T, Elyan M, Kushner I. Pericarditis: a rare complication of methotrexate therapy. Clin Rheumatol 2007;26:2157-8.

8. Mameli A, Barcellona D, Marongiu F. Rheumatoid arthritis and thrombosis. Clin Exp Rheumatol 2009;27:846-55. 